\title{
RECOGNIZING CRITERIA OF "UNITY" IN THE APPLIED AESTHETICS AND THEIR ORIGIN
}

\author{
Fereshteh Pourahmad \\ Master student of Art Research, Shahed University, Tehran, Iran \\ fereshtehpourahmad@gmail.com \\ Mohsen Marasy ( Ph.D) \\ Assistant Professor of Department of Art Research, Shahed University, Tehran, Iran \\ marasy@shahed.ac.ir
}

\begin{abstract}
Nowadays in criticizing artwork, elements and principles that are crucial in creating beauty are examined. the "unity" is one of these principles, that in criticizing art form is considered as one of the most important characteristics of art work because all the elements of art are the result of unity principle. Therefore, in this study is an attempt to recognizing the theory of unity in the applied aesthetics. By studying Western theories of later writers, components and characteristics to achieve this principle were studied and continues to study the origins of this concept among Greek thinkers. The necessity of this research is to understand the applied aesthetics principles in order to achieve a proper understanding of the process and principles of art criticism and achieve common roots and factors of unity principle. The results indicated that the main principle of the unity in the recent west literature, is contrast and harmony . the obtained two components are to be developed in the cosmology debates, creation myths and issues related to the Greek thinker. This suggests that the whole cosmos is based on the principle of unity which requires the existence of two conflicting elements and harmony with the community to achieve such a purpose and can seen confliction to different aspects of the universe. It is a descriptive- analytical research. Library resources were used for qualitative analysis.
\end{abstract}

Keywords: Theoretical Principles of Art, Applied Aesthetics, unity, contrast, harmony, Greece.

\section{THEORETICAL FRAMEWORK DEFINITION:}

Applied aesthetics: the so-called applied aesthetics includes different interpretations of the the concept that has not been presented and there is no detailed definitions of it. With reference to aesthetic resources, the definition of the term can be derived of experts. Applied Aesthetics is studied in this research. It was presented firstly as a philosophic topic. Then, its form was changed. Speaking of this discussion is that what induces a sense of beauty in human and this is not limited to specific experiences and phenomena but it studies all human achievements from a new perspective (Ebadian, 2006). What is relevant to this study, According to Grutter (1375), German architect and thinker, is the theory of dualism ${ }^{1}$ of people like Plato and Hegel. That is what Plato called as Geometric Aesthetics $^{2}$, Hegel called artistic beauty and Le Corbusier called as engineering aesthetics ${ }^{3}$. According to Ocvirk and colleagues (2011), these principles were introduced as some principles to organize image. In this regard, Noel Carroll (2008), American philosopher and art theorist in this century, believes that we pay attention to the art work based on the art work itself. When we pay attention objectiveless at the art work, we evaluated the effect for its own sake, not because of its relation to practical or functional matters, and what is important is what is characterize of aesthetic traits not whether an art work is harmful or beneficial for society. Should give heart to the effect, that allow the structures of work and its objectives guide us. This statement suggests the importance of principles in terms of functional aesthetics, not a certain territory where art work was emerged. In the 
same way no matter which branch even be considered works of art, classic painting, West painting, but artistic principles of the form is the focus of this study which is extended to all other works.

\section{INTRODUCTION}

Art works criticism in ancient times was not raised as an independent activity and merely pamphlets were prepared for different techniques and descriptions of formation of work arts that rarely reached historical definition level and critical definition. This process continued until the fifth century AD, according to art criticism, aesthetics, philosophical arguments in the form of literary criticism was included. The specific orientation of criticism, art can be seen in Plato phylosophy, because in his work he seeks to identify the criteria for evaluating art sculpture and painting works. The same applies was beginning for the relationship between art criticism and philosophy of art as far as we can tell, art criticism, is always practical view of aesthetics. However there are certain principles for criticize applied for criticism and evaluating art works. The same is also important in the production of works of art. These principles were studied since last times including the principle of proportionality. Unity principle is one of the principles its importance ans necessity is felt yet. The importance of unity is that the success of a form of unity is in its structure and is evident in the totality and its visual effects work, unity. Basically, in art criticism topic, paying attention to criteria for obderving unity principle in art works has a specific position. Due to importance of this topic, a proper recognition and indexes for this werk were considered for this principle. However, we have tried to collect all the definitions of unity based on recent research. It is important to note that definitions and theoretical issues have been proposed from the applied aesthetics perspective fully in the visual arts field. Keeping in mind these points, the main questions that this study deals with it is stated as what are the principle of unity after applied aesthetics features? However, so-called applied aesthetics is studied initially. Then, the specifications would be analyzed of western authors.

Main aim of this investigation includes identifying unity principle as image organizing principles based on applied aesthetics and achieving some indexes for criticizing and analyzing works of art. This research is an attempt to identify one of important elements of art theries, also it results in recognizing this principle and applying it is criticizing art works.

\section{METHODOLOGY}

It is a descriptive-analytical research. Both library dta and qualitative analysis were used to collect data. Content analysis method was used in this research to classify collected data. According to Haji luo (2004), content analysis is that in addition to the appearing content, different levels of content is also considered.

Hariri (2006) in data analysis process, after copying, starts by identifying contents and key patterns and making categories of data . it continues by implementing one of the encryption ways. It means that ai of qualitative researcher is to extract concepts of data content. Encoding is a tool for this purpose. Then, the obtained codes and concepts are studied as groups of similar or antithetic groups.

According to Marshal ( 2005), some tables are designed for controlling data . it means that data of qualitative research are complicated increasingly. Grades and groups could be identified and connected by table for this purpose.

\section{LITERATURE REVIEW}

Whereas in recent years some researches have been done in line with art criticism and theory of art, in this area eleven thesis were identified. Furthermore, the sum of forty books and articles with these topics were studied. In the meantime, in the book "Principles of Art: Theory and Practice" by Ocvirk and others (2011) noted that in studying theories of art we face with principles of organizing the elements.

additionally, Herbert Reed in his book "Principles of Art", considered the principle of unity as part of the elements of art work. Therefore, based on the votes of Okvirk and colleagues, this principle will 
be discussed below form as one of the most important features of criticism and analysis of applied aesthetics.

While Rudolf Arnheim in his book "The Art of Visual Perception Psychology of Creative Eye" (2007) has divided principles of composition into two main and sub categories that put the principle of unity and harmony and diversity under the main groups. While Rudolf Arnheim in his book "The Art of Visual Perception Psychology of Creative Eye" (2007) has divided principles of composition into two main and sub categories that put the principle of unity and harmony and diversity under the main groups. main references were studied too for better recognition of unity concept. Including Aesthetic Order- A Philosophy Of Order,Beauty And Art by Ruth Lorand. So given that the concept of unity has not dealt with an aesthetic approach separately and not check its origin, it is considered here.

\section{RESULTS}

\section{CRITERIA OF UNITY OF THE LATE WESTERN AUTHORS}

On the principle of unity in the foundations of art and principles of the organizing image many things have been written.

Ocvirk and colleagues (2011) in the chapter on form, have also been examined unifying principles of organization of the art work. The authors believe that a finished work of art has three components: subject, form and content. Through elements of form, the structural principles of visual discipline studied. Artists control combination and arrangement of elements used by unity principles. These principles are as follows: Harmony, diversity, balance, proportion, control, motion and brevity. These principles create total environment. Unity in this case means the integrity and organizing the elements, according to whole order. Artist uses elements of art structure for producing this final situation, under guiding principles of organization. The unique properties of each element in the process of organizing, are so important that can not be separated. When an artist tries to use line for creating unity to its work, final coordination is created practically in relation to one or all of the features, length, breadth, and quality . unique specifications of each element are exposed to organizing principles . However, the organization in art includes shaping the unified totality of the various units that depend on the duality of similarity and contrast, the balance between harmony and diversity. As coordination is considered as cohesion factors, created both by repetition ${ }^{4}$ and rythem ${ }^{5}$, If it results in indulgence, results in boredom and monotony. However, proper coordination supply is as the most essential components is unity. Artist with coordinated integrates its work, but through reaches unity . but it reaches unity and straction by diversity and . so the visual appeal is a direct result of adding diversity to the video component. About continuity or intuitive category also mentioned that in the early twentieth century, Max Wertheimer, a German psychologist of Gestalt ${ }^{6}$ and colleagues investigated in this regard. how the viewer recognizes factors such as patterns and shapes in terms of the diagnostic groups instead of separately. Actually, conjunction is a concept that produces pattern by collecting factors. Of course, a lot of principles involve in continuity, such as the proximity or similarity law. Discovering the intuitive regulation helped to Wertheimer to explain how the artist sees his work and creates a pattern or organizes structures. For Gestalt psychologists, the whole (general pattern) is beyond which form part of the channel. However the link is between psychological link that make all components as a part of larger component. such as conjunction unites them with displacement and sufficiently close to the objects and figures, other unifying methods of the composition of the elements also close elements together that they are perfectly tangent. Among these methods are the common borders, overlay, transparency, interaction. diversity is another organizing principle. Diversity is one of the organizing principles of balance and is one of essential coordination elements to create unity. with coordination, artist integrated his / her work, but through diversity and charm obtains unity. Attraction is defined as the ability to inspire curiosity and attention of the viewer. If an artist is able to make equal the visual forces, its effect is normalized, while it may be static, soulless and emotionless. Artist introduces main factor of constant paying attention such as diversity. hence, visually interesting is direct result of adding diversity to image factors. Diversity is one of the visual separation factors. This separation (diversity) is obtained using contrast and detail. 
Likewise, in the visual arts, when the contrast is used, the height or the excitement increases. In visual art, it is necessary to emphasize some contrast than others. If you use too much contrast in the composition, constant diversity causes visual disturbance sense. But only few of them can be quite attractive. It seems modes of coordination necessarily correlated with contrast, although the similarity with the difference compared to almost never be found. coordination can overcome the diversity, or the diversity . any relation between harmony and diversity is selected will be changed to the concept or tool helps to explore in other organizing principles. Intelligent use of coordination and diversity helps creating space, and is effective in the formation of balance, movement, proportions, fluency and brevity. Balance is other factor which is vital to reach unity. For this purpose, various factors that contribute to balance work can be stated as: position, location, size, relevance, specificity and direction of visual elements. Another organizing principle useful to achieve unity is proportion which is the ratio between the units or parts of a whole, in terms of size is that when there is ratio between them, these sectors create harmony and balance. Another issue is control. For this purpose, the contrast effect is used to draw attention to the important parts and important sectors are the dominant on art work.

As well, motion is the sixth principle of organizing i.e. eye is directed by visual pathways in a work of art. Brevity is final part of organizing principle. If it is under control of total work, it is remained. If it is disruptive, it is modified or is excluded completely.

Noel Carroll ${ }^{7}$ : Carroll ( 2008) claimed that aesthetic experience is known as aesthetic experience of the art work. Aesthetic specifications are expressive traits of work i.e. some specifications that provide spectacular appearance for the work including handsome, elegant, monumental and formal relations. these traits are classified as unity, diversity, and intensity. according to content-based narration, pay attention to these three components is the aesthetic experience. Carol about diversity acknowledges that the critical reasons of works of art is concerned on having the unity, diversity and intensity for art work. Therefore, any work of art must inevitably emerged to provide unity or diversity for understand of the audience.

While art work without diversity is not necessarily emphasized to make for providing unity for recognition of audience. It is possible that other modes are involved. However, when we speak of the unity, diversity and aesthetic intensity, I mean their impact method on us. It is evident here that unity and diversity are interrelated and together and change together.

Rudolf Arnheim ${ }^{8}$ : Arnheim (1974) stated that principles of composition are divided into sub-divided and main categories that the principle of unity and harmony and diversity is placed under the main group and believes scan of a combination is successful when the elements of each level, concerted action with each other.

Jörg Grutter': According to Grutter (1987), the unity of the effect depends on the ratio of formal relations. If some or all components of work are coordinated completely or partly, the effect is integrated. Integration of art work may be obtained due to an recurring motifs or repetetive themes, which components may are similar to each other in some ways, or they may resemble each other, or components of work may provide unique image for it, such as Tte plot of a story that its elements and components are guided to end of story. When we pay attention to features of the unifying effect and the relations between them, this is aesthetic experience of unity. In other words, the unity is the content or own experience that makes this as an aesthetic experience. However, we can say, recognize something as a whole, at least is a similarity between its parts. This means that when we see something as a whole, there must be similarity between its components at least in one of the fields of the form, size, sex, color or content. Each component type has a significant effect on the expression of a whole. More uniformity of components results in resembling as a whole sooner . if each component is more complete alone, the set is similar to a heterogeneous collection, and total has more distance of homogenius unit. For example, in baroque style, golden proportions rarely used, because these 
proportions impacted less on total harmony and integrity and this is completely contrary to the purpose of the Baroque. Baroque tried to create tension and order the components at a lower level than the whole. If there is difference in one of the components or more, it would be changed to a partial component and would be distinguished of total. As a result, the expression of one totality depends on three factors: the number of components, type of component and component relationships with each other. However, the combination of parts must be done by a specific regulatory system. This is regulatory system that stubbornly maintains the unity between the components because it connects the components together and completely improves coordination and balance. Hence, for example a column of Greek temples is beautiful thing that statue of an Baroque angel, outside its unity in a whole, is not evident. Grutter introduced harmony as a term in the natural sciences and intellectual science often is spoken of it. In aesthetics, coordination or harmony is an order between the components of a phenomenon . coordination is result of any contradictory. This fact is one of the foundations of the East, which Lao Tzu states .also symbols between yin and yang was its symptom . Any type of perception forms only because of conflict, which means that uni is visible only when somehow able to separate itself from its background. Coordination is possible only when conflicts exist. The perception of any kind is ordered based on certain principles in mind. This order can be logical and common sense, or the form and superficial. Result of the first order is scientific change . second result is art change. Harmony is one of main elements of aesthetic architecture. Its practical field is not limited to space dimensions at all. Material, color, sex, appearance and design should be consistent with each other and also be sure that they obey top and widespread order. Physical devices and psychological perception devices all tend to reach a situation where the stress level is reached to a minimum level or in other words, is more balanced. So that, for example, the position is not quite right by our perceptual system itself is close to 90 degrees. Against any provocative combination, is always its visual perception set to find a visual balance possibly. When watching a proper mix, it makes sense for us, however, that each component is exactly at the right place and any change in that, is interpreted in our mind as disorder. Imbalance impacts contrary on viewer. Lack of ensurance is its result. There is a balance in our perception when we see that all the forces in the field, mutually neutralize each other. Two factors are very important here as weight and force direction. Quite apart from any possible physical weight, each figure has a weight perception that isunder various effective functions. For example, appearance form has a major role in this regard. Size, form, color and darkness and light all are affective in perceptive weight. For example, a light-colored object may seem that the weight of the smaller object with darker color. Another factor is the apparent mass. For example, a small building that is constructed of concrete may be perceived in terms of the weight of a building the size is much larger with the roof of the tent. next factor is the content value of material that itself is under control of psychosocial-social factors strongly.

For example, a tomb or a monument can be perceived in terms of building a warehouse is heavier because such buildings has attracted more attention to them and their effects. parallel to weight, direction impacts also on the visual balance perception. Mobile forms have direction. Finally, semantic information of a phenomenon or its indications provide direction in mind. For example, a car or a flash stand are with direction for mind. As a result, according to Grutter, three factors as the number of components, type of component and component relationships with each other, result in the harmony and proportion in total work . Consequently, imbalance associates with work uncertainty.

Pierre $\operatorname{von}^{10}$ : Pierre von(2011) acknowledges based on Pierre von theory also that, order makes sense only when it is associated with chaos and confusion. Discipline itself has no value unless it is within limits framework. General order and chaos immersive, both equally makes difficult circumstances that would be intolerable in the long time.

George David Birkhoff ${ }^{11}$ : in 1933, Birkhoff made a method for calculating beauty feel. This size can not simply be described as beauty size, but this size is the most important measurable component in beauty feeling. Perception needs effort. amount of this effort depends on the complexity of what we are trying to feel it. 
This complexity is one of the traits of our subject and something that can be demonstrated with numbers. The result was that the pleasure derived from the work of art or a beautiful object depends on two variables.one of them is order level of unique of object is shown by $\mathrm{O}$ as abbreviation of Order. The other one is $\mathrm{C}$ which is abbreviation of Complexity. Actually, each message is formed of some signs. Number of these signs has direct relationship with $\mathrm{C}$ number. In addition, he considered $\mathrm{M}$ for pleasure level of aesthetics. This formula is determined for that : $\mathrm{M}=\mathrm{O} / \mathrm{C}$. Also signs of a message, communicate with each other, in other words there is confusion between them.

Birkhoff is recognition of this order as necessary discipline for creating a sense of charm. This order presents in a way that symmetry is one of them. In addition, an object is very beautiful when it presents the most possible order. But it should be noted that this does not mean that a subject is regular whatever is beautiful. Birkhoff has tested his formula about lots of samples of art works in the field of music and poem and samples of ornaments and vases. Here are just a few examples of aesthetic calculated of a few pots. Forms of all pots are Rotational symmetry. outline form are pointed in test. Also decorate of the surface and frills of pots are not considered . To determine the complexity of the "C" , Birkhoff used the index points. These points are places that attract the viewer's attention more. the most important indicator points are these points: A) four-points limit out sides of figure in their own. B- some points of the curve where is the horizontal and vertical tangent. C- Vertices.Dsome points of figure where curve shift the curve (milestones). E) crosses of the vertical axis with horizental lines that diameter diagram are the largest and smallest circular shapes. To calculate the size of the order "O" Birkhoff, four factors are taken into account.

Birkhoff determined these four factors by the fact that horizontal and vertical lines that are equal or times there is 2.1ratio between their length are perceived in a particular combination:

A) the creation of embryos proportions by index points on the vertical line (V).

B) the emergence of such proportions by the number of index points on the horizontal line $(\mathrm{H})$.

$\mathrm{C}$ - number of creating such ratio are counted by index points on vertical and horizontal points without counting ratio counted in parts A and B ( HV).

D- number of creating such tests by index points on Tangents points . hence, calculating size aesthetic value is obtained from the following formula:

$$
\mathrm{M}=\mathrm{H}+\mathrm{V}+\mathrm{HV}+\mathrm{T} / \mathrm{C}
$$

Birkhoff formula is usable just in specific parts . it is not possibl to consider it as a base for a complete theory including aesthetic perception. For example the formula is limited in the framework of symbols theory because by it can not becalculated the full value of the aesthetic. In this calculation viewer with all its special attributes did not intervene. Birkhoff may assess composition of a part of music in this way, but it is not possible to assess the performance of the piece by a specific artist.

Feeling provided by this piece of music to each audiences is not meqasurable at all (Lorand, 2000).

Robert Venturi ${ }^{12}$ : Venturi (1966) commented that, I prefer being alive, whatever they may be demonstrated badly than boring unity. I think the diversity of ideas is superior to clearly know. In my mind, hidden and sealed concepts are important the same as statements. A good architecture addresses the different levels and offer different modes of communication. Its atmosphere and its components can be used and are understandable in different ways and simultaneously.

Le Corbusier $^{13}$ : One Max (2009) in description of Le Corbusier writes, making is called a correct communication and synergies between structural elements because the design of a building is nothing more than putting together a collection of individual components with clearly defined of mathematical logic of - A technique, economic and aesthetic rules.

Edmund Burke Feldman ${ }^{14}$ : in 1992, Feldman in definition of unity asserted that possibly unity is main principle of visual part. Surely there are other principles under service to develop its unity each one. Finally, unity is a natural reflection of the fact that each human is a separate unit, and a separate apparatus sees, feels and thinks by his / her body and brain .we all are separate totals in ourselves. 
Naturally, we should separate our sight experience of something in minute to be able to view other thing. Determine the nature is main reason of our naturally need to have sight unity. Artist tries to organize parts of each artistic work to provide a unified total in front of sights of viewer. Failure to meet this goal, i.e.the ineffectual design, makes viewer to turn away watching it earlier. Such turning away to the validity of the above passage, is not ending the visual experience to begin an experience, but cut relation to the work of art, and failure are experiences that must have been fruitful. Therefore, the objective of plan out of the hands of the artist must be creating unity of a good work, voluntary unity among the components before the components are placed in front of or viewer.

Such methods could be considered to achieve this goal: 1) domination and dependency or dexterity and subordinate of elements is in relation to each other. 2) to bring together dissimilar forms 3) the unity of symmetrical lines and radial lines. What is important is dominant causes presents something including differentiation and cohesion (integration of belonging to each other). In fact, the artist provides sequence among the visual phenomena . it considers the duration of attention should be paid to each of them. prevail element over all works is that it provides dependency between itself and other elements of the intellectual content and eyes value. Dominance in the early stage is obtained by a large-size which is the easiest way, because a larger form has seen before settling in smaller forms. in the next step,dominance is ensured by strong colors, because warm color sits at background and attracts viewer sooner. Locate in the picture is another method to show dominance in image, because eyes of human usually pay attention to center of view field . That is why it is generally in making face, head and face are placed in equal distance of riht and left a little upper than center point of canvas. Further, the symmetrical way of lines and shapes on the drawing page depth, such as radiation of lines and shapes of a place to surrounding area, causing up to its dominance areas of images. Brightness is another dominant factor and the brightness knows the less to resist the allure of the place or shining element . although sunlight hurts our eyes, we gaze it sometimes uncontrollably. Thus a brighter section of painting is also dominated on darker areas of surroundings, as the Sun dominantes across the sky. Finally, dominance is visualized by distinction. We all know that eccentricity forms or appeals to the eye: if an oval shape is placed among a large number of rectangular forms, and a ball falls among masses scattered bricks, as an exceptional element, sits out and becomes visible. On the cover of a famous novel, a figure similar to green sprouts in the enclosed space between the brick walls of the bulky yellow is drawn. This figure attracts our attention firstly, because its figure is the same and is exceptional too. Also, we image haggard tree shape in our mind before walls around it. In one definition, solidarity means affiliation or belongs to each other among parts of art work. Some parts may be separated to each other completely in life, but in art work, colors, figures, sizes, tissues, etc should integrate with each other to the extent that seem inseparable from each other, but in art work, colors, figures, sizes, tissues, should integrate to the extent that seem inseparable from each other. The concept of coherence is with miraculous property. Our reaction toward a coherent work is that we see ourselves in front of a live inherent, what its life is in its unity. Here is where the organizer finds out that design elements or art work is inevitable, but this could be and still is . Visual coherence often is achieved using color and the same hue, a single color across the screen. Any other similarities in shape, color, size, texture, or lighting can also add coherence to the property. The similarities entails some risks too. high similarity may result in monotony and boredom. Our tolerance is limited to consistency, because we all need to diversify. With dissimilar forms can be put together to form unity, which is near the continuity inductor. When dissimilar figures are in a large environment, they seem as a unit, because eyes of human prefers similarity than difference and proximity to isolation. In addition, unity of converging lines and radial lines is not easily applicable and take advantage of it is quite common in painting and sculpture.

In addition, Feldman believes that unity is main principle of visual part, and reach perfection other unity principles. Organizing art works is required for reaching a unified totality. Existence of unity in other natural realities such as human kind is reason of unified totality importance. Each human is separate unit, i.e. they are separate totality. hence, he has pointed out to unity of nature too. 
Francis D.k.ching ${ }^{15}$ : according to ching (2009), Order alone and simply does not originate from a regular geometry, but more so, it refers to a state that any component of a whole in place, is in its worthy place than other parts . order without diversity results in monotony and boredom. Diversity without order results in chaos. therefore, a feeling of unity along with diversity is desirable ( table 2-1, 2-2).

Table 1-2. Some common and subscribers factors of unity among Western authors.

\begin{tabular}{|c|c|c|c|c|c|c|c|c|c|c|c|c|}
\hline & $\begin{array}{c}\text { factors } \\
\text { people }\end{array}$ & $\begin{array}{c}\text { Coor } \\
\text { dinat } \\
\text { ion }\end{array}$ & $\begin{array}{l}\text { Div } \\
\text { ersit } \\
y\end{array}$ & $\begin{array}{l}\text { Bala } \\
\text { nce }\end{array}$ & $\begin{array}{c}\text { Propo } \\
\text { rtional } \\
\text { ity }\end{array}$ & $\begin{array}{c}\text { Domin } \\
\text { ance }\end{array}$ & $\begin{array}{c}\text { mot } \\
\text { ion }\end{array}$ & $\begin{array}{l}\text { Bre } \\
\text { vity }\end{array}$ & $\begin{array}{c}\text { Inten } \\
\text { sity }\end{array}$ & $\begin{array}{l}\text { Repe } \\
\text { tition }\end{array}$ & $\begin{array}{c}\text { Weig } \\
\text { ht }\end{array}$ & $\begin{array}{c}\text { Force } \\
\text { directi } \\
\text { on }\end{array}$ \\
\hline \multirow[t]{10}{*}{$\begin{array}{l}\text { Western } \\
\text { authors }\end{array}$} & $\begin{array}{c}\text { Ocvirk } \\
\text { and } \\
\text { colleagues } \\
(2011) \\
\text { along with } \\
\text { Gestalt } \\
\text { theory }\end{array}$ & $*$ & $*$ & $*$ & $*$ & $*$ & $*$ & $*$ & & & & \\
\hline & $\begin{array}{c}\text { Noel } \\
\text { Carroll }\end{array}$ & * & $*$ & & & & & & $*$ & & & \\
\hline & $\begin{array}{c}\text { Rudolf } \\
\text { Arnheim }\end{array}$ & $*$ & $*$ & & & & & & & * & $*$ & $*$ \\
\hline & $\begin{array}{c}\text { Jörg } \\
\text { Grutter }\end{array}$ & * & * & & & & & & & & & \\
\hline & Pierre von & * & $*$ & & & & & & & & & \\
\hline & $\begin{array}{c}\text { George } \\
\text { David } \\
\text { Birkhoff }\end{array}$ & * & * & & & & & & & & & \\
\hline & $\begin{array}{c}\text { Robert } \\
\text { Venturi }\end{array}$ & * & $*$ & & & & & & & & & \\
\hline & $\begin{array}{c}\text { Le } \\
\text { Corbusier }\end{array}$ & $*$ & $*$ & & & & & & & & & \\
\hline & $\begin{array}{l}\text { Edmund } \\
\text { Burke } \\
\text { Feldman }\end{array}$ & * & $*$ & & & & & & & & & \\
\hline & $\begin{array}{c}\text { Francis } \\
\text { D.k.ching }\end{array}$ & * & $*$ & & & & & & & & & \\
\hline
\end{tabular}

Table 2-2- main factors of unity principle based on viewpoints of western autors

\begin{tabular}{|c|c|c|}
\hline Factor & Other items & Common definitions \\
\hline Harmony & $\begin{array}{l}\text { Similarity, unity, } \\
\text { integrity, discipline, } \\
\text { legitimacy, coherence } \\
\text { and coordination. }\end{array}$ & $\begin{array}{l}\text {-discipline among the } \\
\text { constituent members. } \\
\text { - wrapping everything in its } \\
\text { seat. } \\
\text { - } \quad \text { Integration factor. }\end{array}$ \\
\hline
\end{tabular}




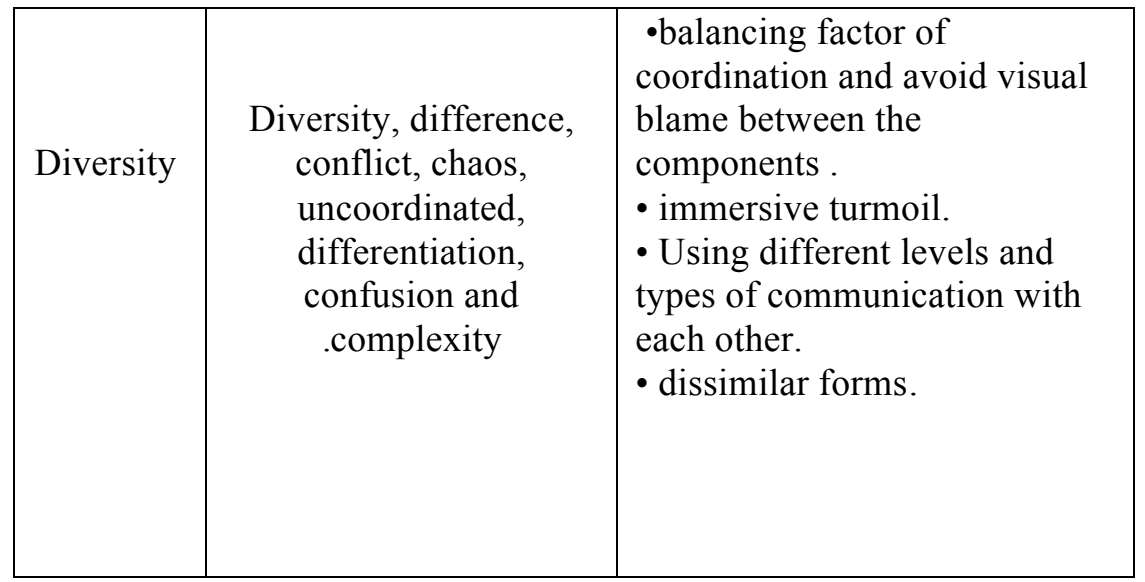

\section{THE ORIGINS AND HISTORY OF THE THEORETICAL FOUNDATIONS OF UNITY}

Continue to it, we investigate the background of the theoretical basis that is centered on the conflict and harmony, because according to studies conducted, indicators of this principle is recognizable among theories of greek philosophers who spoke about cosmology ${ }^{16}$. According to Esmail Poor ( 2005), in fact, the first Greek philosophers to discuss themes and concepts that they are all rooted in the mythological culture. Like the words of $\mathrm{Hesiod}^{17}$ when we look at such old documents, all speak of a type of disorder that gradually organized and order has dominated in the universe. Thus, Reeves and colleagues (1386), acknowledge that the history of science is concerned with how the world of early stage irregularities come to the diversity existing today, while its military is more organized and more efficient. Also, according to the Geneva (2011), the importance of cosmology is the most one that can be described as the theory of cosmic unity and harmony in the Hellenistic era to the Renaissance. This coordination includes as links and even four element mixing of what the human and before that, the universe is made of it. In fact, the four elements of water, fire, air and soil, in addition to the universe, include humans body parts too. Given that forces of four elements are always in conflict with each other must be in harmony with each other because of the combination of the two of them all the creatures of the universe was made. However, these four elements are the first form of sustainable world that many Greek thinkers have dealt with it. Among them, Aristotelian theory of opposites, is significant because fire in front of the weather is in front of the soil. In fact, the elements can not exist without each other, but conflict with each other and situations of all the creatures are so. According to lindburg (2008), With the appearance of Greek philosophy in the sixth century, a group of thinkers began a serious research into the nature of the world in which they lived and what it is. Due to it, they were called naturalists.

According to Zamiran ( 2006), as philosophy started by the idea of Thales (546-640 BC), he is also the first naturalist philosopher who placed all of phenomenon of world under a specific element i.e. water, and knews all phenomenon of world as different forms of water. Due to it, he is the first philosopher who explained the duality of the universe and the concept of unity in diversity and plurality of view objects and phenomena. After that, the elements of conflict and harmony in the universe of Naksymandrs idea of justice in the realm of theory and debate coordinating a whole of Stoic Logos, the unity of opposites, wisdom, the essence of being and order of the universe from Heraclitus be investigated.

After that, other elements are investigated as conflict and harmony idea of justice in the realm of cosmetics of Anaksymandres, coordinating theory in components of a totality of Stoic and Logos discussions, the unity of opposites, wisdom, the essence of being and order of the universe from Heraclitus. Also Parmenides, Empedocles, Anaxagoras, Pythagoras, Plato, the Neoplatonists, on issues related to the creation of the universe, discussed about antithetical nature of elements of the universe. In addition, as noted earlier, the constituent elements of the Aristotelian world, combined of 
two different qualities or opposing elements that will eventually lead to coordination are significant . Galen also considered the four elements (Table 3-1 and 4-1).

Table 3-1. Subscribers and non-subscribers categories consisting of the elements of unity (harmony and conflict) among Greek thinkers

\begin{tabular}{|c|c|c|c|c|c|c|c|c|c|c|}
\hline & $\begin{array}{c}\text { The } \\
\text { Four } \\
\text { Elem } \\
\text { ents }\end{array}$ & $\begin{array}{c}\text { Ligh } \\
\text { t and } \\
\text { dark } \\
\text { ness }\end{array}$ & $\begin{array}{c}\text { Spirit } \\
\text { and } \\
\text { materi } \\
\text { al }\end{array}$ & $\begin{array}{c}\text { unit } \\
\text { and } \\
\text { pluralit } \\
\mathbf{y}\end{array}$ & $\begin{array}{c}\text { Limited } \\
\text { and } \\
\text { unlimit } \\
\text { ed }\end{array}$ & $\begin{array}{c}\text { Justi } \\
\text { ce } \\
\text { and } \\
\text { injus } \\
\text { tice }\end{array}$ & $\begin{array}{c}\text { Good } \\
\text { and } \\
\text { Evil }\end{array}$ & $\begin{array}{c}\text { Love } \\
\text { and } \\
\text { hate }\end{array}$ & $\begin{array}{c}\text { The } \\
\text { ultimate } \\
\text { and the } \\
\text { subject } \\
\text { cause }\end{array}$ & $\begin{array}{c}\text { Existence and } \\
\text { appearance }\end{array}$ \\
\hline $\begin{array}{c}\text { Thales } \\
\text { s }\end{array}$ & & & & & & & & & & \\
\hline Stoics & & & $*$ & & & & $*$ & & & \\
\hline Heraclitus & $*$ & & & & & $*$ & & & & \\
\hline Parmenides & $*$ & $*$ & & & & & & & & \\
\hline $\begin{array}{c}\text { Empedocles } \\
\text { and }\end{array}$ & $*$ & & & & & & & $*$ & & \\
Anaxagoras & & & & & & & & & & \\
\hline Pythagoras & & & & & $*$ & & & & & \\
\hline Plato & $*$ & & $*$ & & & & $*$ & & & \\
\hline $\begin{array}{c}\text { Neoplatonist } \\
\text { s }\end{array}$ & & & & $*$ & & & & & & \\
\hline Aristotle & $*$ & & & & & & & & & \\
\hline Galen & $*$ & & & & & & & & & \\
\hline
\end{tabular}

Table 4-1. The importance of the issues involves the concept of unity (harmony and contrast) based .on the frequency in Greek thought

\begin{tabular}{|c|c|c|}
\hline Categories & Frequencies & Result \\
\hline Four elements & 7 & \multirow{10}{*}{$\begin{array}{c}\text { So in discussing the four } \\
\text { elements including light and } \\
\text { darkness, spirit and matterial, we } \\
\text { observe the most appearance of } \\
\text { the elements of unity (harmony } \\
\text { and contrast. ( }\end{array}$} \\
\hline Light and darkness & 5 & \\
\hline Material and spirit & 5 & \\
\hline unit and plurality & 1 & \\
\hline Limited and unlimited & 2 & \\
\hline Justice and injustice & 2 & \\
\hline Good and Evil & 2 & \\
\hline Love and hate & 1 & \\
\hline $\begin{array}{l}\text { The ultimate and the } \\
\text { subject cause }\end{array}$ & 1 & \\
\hline Existence and appearance & 2 & \\
\hline
\end{tabular}

\section{CONCLUSION}

According to recent surveys conducted in Western sources, from the perspective of each of the authors, some constituents and characteristics are intended. from their results, main components to assess the aesthetic component works on the principle of unity was achieved .Notably, based on the prepared table some of the components are common among authors. Thus, among them two factors as coordinates and conflict are preferred than the rest with the aim of achieving the principle of unity. Although various titles such as similarity, integrity, discipline, cohesion for coordination, and diversity, chaos, complexity and differentiation for conflicts were intended. In fact, given that sum of the opposites is impossible, these two are added together, and appear in a third element that will be common to the two opposing principles. In next stage, root of factors obtained of greek philosophers were obtained, and the intended concept was obtained in cosmology topic and creation myths.as a 
result, it was found out that in the creation of the universe, link of two opposing elements is the basis of creation. This means that in an element, contradiction and harmony are associated with each other . notably, in Genesis stories such stories is that the third creature is as result of two opposing elements, thre is always common with other opposing principles that the case was necessary to link them.

The two opposing principles have been examined in various ways. four elements, light and darkness, spirit and matter, the microcosm and the Great are main principles that unity principle have been raised in them.

\section{SUBSCRIPTS}

1. Dualism ( Esmail Poor, 2002).

2.Geometric Aesthetics

3. Engineering Aesthetics.

4. "again using a similar visual effect in a Unit combination " (Ocvirk et.al, 2012).

5. "continuing, current or movement sense that comes with a regular repeating of visual units" (ocvirk et.al, 2012).

6. result of Gestalt theory in perception of figure is that a figure is a composed organization that can not be considered as a set of elements beside each other, because it has a unique quality . changing in one element changes total form of it. Gestalt psychologists found out that brain do it according to some principles. They knew it as principle of approach to similarity, closure, continuity and relaxation.they believe these factors are necessary for organizing visual elemets ( Leyliyan et.al , 2009).

7. noel Carroll born in 1947 , American philosopher, as theorists of cognitive theory and inventor of Post-Theory (https://guionterror.files.wordpress.com, 2015).

8.born in 1904 , berlin, psychologist, German aesthetics and film theorist (Zabeti Jahromi, 2008).

9.born in 1948, educated in architecture field of study in German and Japan( Grutter, 1987).

10. Pierre Von Meiss, born in 1938, Switzerland, architects and designers and theorists in recent 30 years, and has numerous books on architecture (http:// people.epfl.ch, 2015).

11.born in 1884, died in 1994, American Mathematician (Grutter, 2005).

12. he was born in 1925 in Philadelphia, Pennsylvania, architecture degree, undergraduate and graduate received in 1947 and in 1950 from Princeton University. He gained general reputation by his book Complexity and Contradiction in Architecture in 1966 (Venturi, 2010).

13. Lo korboziye, born in 1887-1965, Swiss-born French architect, who considered as one of four great masters of modern architecture (Anvari, 2009).

14. emeritus professor of Art and owner of some encyclopedia of university. He is also shown as ....of art exhibitions and educational consultant of visual arts and now is president of the National Art Education involved in the founding of Home School of Humanities (Burke Feldman, 2009).

15. Francis D. K. Ching ( 1943), Professor of Architecture and Design and the author of form, space and order (Ching, 2003).

16. Cosmology: Cosmology first by the Greeks, in particular Thales (625-547 BC) and Anaksymandrs (610-540 BC), appeared as a field of science. The word cosmology is derives from the Greek word (Cosmos). Cosmos means the universe as a whole and regular system, which unity and integrity are essential for it as well. it emphasis both on the word order and on completeness, because in Greek language, Cosmos (Cosmos) is opposed to the word of disorder and chaos (Kells, 2010).

17. 1. Hesiod: Greek ethics poet who in $700 \mathrm{BC}$, flourished. he was son of a captain from Ascra, a city at the foot of Mount Helicon. One of the first Greek poet lived shortly after Homer . some of his works included works and days and famous teogony (Dixon Kennedy, 2006).

\section{REFERENCES}

Esmail Poor, Gh, 2003, Creation myth in Mani's religion. Tehran, Iran. Caravan.

Noori, Hasan, 2008, Sokhan confirm culture. Tehran: Sokhan.

Ocvirk, Stinson, Wigg, Boon, Cayton (2011). Art Fundamentals: Theory and practice. translatied by M.R. Yeganedoost, Tehran, Samt.

Bork Feldman, Edmond, 2009, a variety of visual experiences. Tehran: Soroush. 
Hariri, Najla, 2006, Principles and methods of qualitative research. Tehran: Islamic Azad University, Science and Research.

Hajiloo, H.A.2005, The introduction of qualitative data analysis techniques with emphasis on content analysis. Journal of Management tomorrow. N. 7 and 8. 62-55.

D.K.Ching, 2009, architecture, form, space, order, translated by Zahra Torkaman, Kazm Kamali Nasab, Tehran, Malaek.

Dixon Kennedy, Mike (2006). Encyclopedia of Greek and Roman mythology. Translation Roqiyeh Behzadi. Tehran: Tahoori.

Reeves, Hubert and others. (2007). Origin of the universe, life, people, language and culture. Jalaluddin Rafifar. Tehran, Iran. Agah

Zhinio, Philip, 2011, humans and the universe in ancient Iran . translation by Linda Goudarzi. Tehran: Mahi.

Zabeti Jahromi, Ahmad, 2008, Rudolf Arnheim review cinematic theory. Spring art. No. 35. pp. 214223.

Zamiran, Mohammad, 2005, The transition from the myth world to philosophy. Tehran, Iran. Hermes. Ebadiyan, M, 2005, Proceedings of the meeting of applied aesthetics. Tehran: Ministry of Culture and Islamic Guidance.

Carol, Noel, 2008, Introduction to the Philosophy of Art. translations by Saleh Tabatabaei . Tehran: Iran's Academy of Art.

Kells, Peter and Haghighi, Nadia (1390). Cosmology. Tehran: Basirat.

Grutter. Jorg. (2005). Aesthetic architecture. translation by Jahanshah Pakzad and Abdulreza Homayoon. Tehran, Iran. Shahid Beheshti University.

Liliyan , Mohammad Zaman and Amir Khani, Ariyan ( 2009), Essay based on the concepts of aesthetics and its manifestation in architectural structures. Art book Monthly, No. 137. 55-50.

Lindberg, David C.. (2008). Beginnings of science in the West, European Scientific Tradition in the philosophical religious context and its facilities: $600 \mathrm{BC}$ to $1450 \mathrm{AD}$. Tehran, Iran. Scientific and Cultural Organization.

Marshall, Catherine and Gretchen B and Rossman (2006). Qualitative research methods. Translation by Muhammad Ali Parsaeian and Mohammad Araie. Tehran: Cultural Research Bureau.

Venturi, Robert (2010). Complexity and Contradiction in Architecture. Translated by Seyyed Ali Reza Mir Torabi and Mohammad Reza manouchehri. Tehran: Samira.

Howard Baker, Geoffrey (2008). Design strategies in architecture. Translated by Mehrdad Matin. Tehran: Islamic Azad University Center.

Arnheim, Rudolf (1974). Art and Visual Perception: A Psychology of the Creative eye .Berkeley, Losangeles, London: University of California press.

https://guionterror.files.wordpress.com/2010/11/philosophy-of-horror.pdf, (2015/01/05)

Ching, Frank (Francis D.K.), and Winkel, Steven R(2003). Building Codes Illustrated: A Guide to Understanding the 2000 International Building Code. John Wiley. Hoboken.

Feldman, Edmund Burke (1992). Varieties of Visual experience. New York: Abrams.

Meiss, Pierre von (2011). Elements of Architecture: from form to place. London and New York: Routhledge.

Lorand, Ruth (2000). Aesthetic Order: A Philosophy of order, Beauty and Art.London and New York: Routledge.

Grutter, Jorg Kurt (1987). Asthetik der Architektur: Grundlagen der Architekture-Wahrnehmung. German: W.Kohlhammer.

Venturi, Robert (1966). Complexity and Contradiction in Architecture. New York: The museum of modern art.

Von Moos, Stanislaus(2009). Le Corbusier, Elements of a Synthesis. Rotterdam. 